\title{
Flexible Small Firms? Why Some Small Firms Facilitate The Use of Flexible Workplace Policies
}

\author{
Catherine E. Gordon \\ Julie A. MCMulLin \\ Tracey L. Adams
}

\begin{abstract}
This paper examines why some small firms offer Flexible Workplace Policies (FWPs) while others do not and what factors contribute to the offering and use of FWPs within small firms. A multiple case study is employed using multiple data sources on seventeen information technology (IT) small firms in Canada. Findings reveal three types of firms with regard to their flexibility, working hours, and approaches to time. Among these firm types, discernible patterns emerged based on the owners' past employment experiences and personal approaches to work-life balance. Our results suggest that structured social relations experienced through past places of employment have lasting effects on small firm owners in their current firms.
\end{abstract}

Keywords: flexible workplace practices, alternative work arrangements, workplace cultures, life course, work-life integration, small firms

Résumé. Cet article examine la raison pour laquelle certaines petites entreprises proposent des politiques de lieu de travail flexible alors que d'autres ne les offrent pas; l'article se penche aussi sur les facteurs contribuant à la prestation et à l'utilisation de ces politiques par les petites entreprises. Une étude de cas multiples est utilisée, faisant appel à des sources de données multiples de 17 petites entreprises de technologie de l'information (TI) au Canada. Les conclusions révèlent trois types d'entreprises en ce qui concerne la flexibilité, les heures de travail et les approches du temps. Certains modèles visibles se dégagent parmi ces types d'entreprises selon les expériences antérieures et les approches de conciliation travail-vie du propriétaire. Nos résultats indiquent que les relations sociales structurées vécues dans des lieux de travail antérieurs ont des effets durables sur les propriétaires de petites entreprises dans leur fonction actuelle.

Mots clés: pratiques de lieu de travail flexible, réaménagement des horaires de travail, culture au travail, parcours de vie, intégration travail-vie, petites entreprises 


\section{INTRODUCTION}

ecently, more workers are having difficulty balancing work and family demands (Christensen and Scheider 2010; Duxbury and Higgins 2003; Korabik et al. 2008). The prevalence of dual-career couples, the rise in single parent families, and the increasing participation of men in providing child care (Marshall 2006, 2009), have resulted in more work-family conflict as families struggle to balance the competing responsibilities of paid and unpaid labour. To minimize this conflict, men and women have pursued a variety of individual strategies, often relying on extended family support, and complicated child-care arrangements that allow parents to be at work for fixed hours every day. Workplaces have lagged behind in supporting these endeavours and fostering worklife balance; they still typically lack policies that allow workers the flexibility to negotiate work and family responsibilities.

Flexible Workplace Policies (FWPs) refer to arrangements that give workers some choice about where, when, and for how long they perform their work (Hill et al. 2008; Korabik et al. 2008); FWPs involve altering the location of where work is performed (e.g., at home on an occasional or permanent basis), the scheduling of when work is performed (e.g, flex-time, variable work days or weeks), or the number of hours worked (e.g., taking extended breaks during the workday, reducing hours). These arrangements, in turn, help with the management and negotiation of work and family responsibilities, reduce stress, and enhance quality of work experiences (Higgins et al. 2008; Korabik et al. 2008; Lowe and Schellenberg 2001). Yet, the potential benefits of FWPs are often lost because they are not widely available to Canadian workers (Ferrer and Gagné 2006; Higgins et al. 2008; Zeytinoglu et al. 2009). Firm size is a key contributor to the likelihood that a workplace will offer FWPs and past research consistently shows that, compared with large firms, small firms are less likely to provide employees with flexible employment options (Dex and Scheibl 2001; Ferrer and Gagné 2006; Kalleberg et al. 1996; Pitt-Catsouphes and Litchfield 2001; Zeytinoglu et al. 2009). ${ }^{1}$ Notably,

1. Measurement of smaller enterprises varies in each study. Small- to mediumsized enterprises (SMEs) employ under 500 workers in Dex and Scheibl (2001), small firm size is 1-49 (medium is 50-499 and large is 500 and over) in Pitt-Catsouphes and Litchfield (2001) and is under 25 in Ferrer and Gagné (2006). SME size is unknown in the Pohlmann and Dulipovici (2004) study but according to the website of the Canadian Federation of Independent Business (CFIB), the organization that conducted the study, small firms employ under 50 people and mid-size firms employ between 50 and 499 people (combination $=\mathrm{SME}$ ). The log number of employees is taken in Zeytinoglu et al. (2009) and in Kalleberg et al. (1996) to reduce the skew of larger firm sizes. 
small businesses (with less than 100 employees) employ 69.7 percent of the total, private sector labour force in Canada (Industry Canada 2013).

Most of the research on FWPs within workplaces has been conducted in large firms with the results often thought to be relevant for small firms as well. Indeed, there is a tendency in the literature to assume that the same FWP implementation and utilization processes occur in small and large firms alike. Potential differences between small and large firms with respect to how and why FWPs are put into place tend to be neglected (Lero and Lewis 2008; MacDermid et al. 1994; Pitts-Catsouphes and Litchfield 2001). Furthermore, theories have been put forth to explain why small firms do not offer FWPs (e.g., institutional theory) but these theories do not explain why some small firms do provide flexible workplace policies and practices for their employees. This paper adds to the current knowledge on FWPs by examining differences among small firms regarding whether they offer employees flexibility in their work. Using qualitative data from small, information technology (IT) firms, we ask why some small firms offer FWPs while others do not and what factors contribute to the offering and use of FWPs within small firms.

\section{INSTITUTIONAL THEORY: WHY SMALL FIRMS DO NOT OFFER FWPS}

Researchers often draw on institutional theory to explain why small firms are less likely to offer FWPs compared to large firms (Blair-Loy and Wharton 2002; Davis and Kalleberg 2006; Ollier-Malaterre 2009). According to this theory, organizations confront three kinds of institutional pressures that influence whether particular Human Resources (HR) benefits, like FWPs, are established (DiMaggio and Powell 1983; Meyer and Rowan 1977). These pressures, referred to as isomorphisms, include coercive, mimetic, and normative, and they tend to affect firms that are more visible to the public (Blair-Loy and Wharton 2002; OllierMalaterre 2009). Ergo, small firms are likely to receive less scrutiny if benefits are not established.

Coercive isomorphism refers to legislative requirements and cultural expectations. Employers in Canada are not legally required to offer FWPs but societal pressures to be "family-friendly" and supportive of employees' work-life needs are present. These expectations are exemplified in the top 100 employer lists published that identify companies with the best work-life policies like FWPs (see e.g., CNN 2014). The reputation of smaller companies is not necessarily tarnished if they do not make these lists, which larger companies tend to dominate. Mimetic isomorphism occurs when organizations model themselves after other 
organizations, intentionally or unintentionally, in response to uncertain conditions. This institutional pressure is not often used to explain why firms establish FWPs. Possibly, firms struggling to retain or recruit highly skilled workers match the benefits available at competing firms. Normative isomorphism comes from professional associations, such as the Human Resources Professional Association. Small firms typically do not confront this isomorphism because HR personnel, who initiate and promote FWPs, are often absent (Kalleberg et al. 1996; Pohlmann and Dulipovici 2004).

Whereas much of this past research draws on institutional theory to explain differences between large and small firms, Davis and Kalleberg (2006) test its explanatory strength. Using representative data on firms in the United States from the National Occupational Survey (1996-1997), Davis and Kalleberg examine whether institutional theory can explain why some firms establish work-life policies that include the FWP of flexible scheduling. The indicators of institutional theory are examined separately and include firm size, equal reporting (whether firms are required to report their workforce demographics to government agencies), formalization (the level of documentation that exists), the presence of HR personnel, and whether firms are attuned to the training practices of other organizations. They reflect the isomorphisms discussed above.

Davis and Kalleberg (2006) find that firm size does not determine the odds of whether an organization offers flexible scheduling. Neither does any indicator except the mimetic pressure of being attuned to the training practices of other organizations, which increased the odds of flexible scheduling being available. Consideration, however, of the strong link between large firm size and the presence of equal reporting, formalization, HR personnel, and being attuned to other organizations, lead Davis and Kalleberg to argue that large firms receive greater scrutiny compared to small firms and this influences the establishment of FWPs. What is left unexplained is why some small firms do offer FWPs. Perhaps these firms are responding to mimetic isomorphisms to be like large firms, but this claim has yet to be made in the literature.

\section{FWPS IN SMALL FIRMS}

The likelihood of small firms offering FWPs may be lower compared to large firms, but flexibility is apparent among some small firms (Dex and Scheibl 2001; Ferrer and Gagné 2006; Lewis and Cooper 2005; Pohlmann and Dulipovici 2004). Possibly, the flexibility of small firms is underestimated in the literature, which typically asks about the FWPs 
available through HR policies (Atkinson and Hall 2009; Lero and Lewis 2008). In small firms, FWPs are more likely to be offered through informal negotiations than HR policies (Dex and Scheibl 2001; Lewis and Cooper 2005; Pohlmann and Dulipovici 2004). Informal FWPs are unofficial and involve undocumented negotiations between employees and their supervisors (Eaton 2003). Small firm owners and managers, who assume HR responsibilities in response to the absence of HR personnel, prefer to address employees' needs as they arise and on an informal basis (Pohlmann and Dulipovici 2004). Accordingly, small firms tend not to have formalized procedures and are considered unstructured organizations (Davis and Kalleberg 2006; Edwards 1979). This research suggests that FWPs are available in small firms because of employees' requests (Pohlmann and Dulipovici 2004), but this explanation leaves out one powerful party - the owners. Both parties involved in the informal negotiations of FWPs are potential sources of FWPs in small firms.

In independent small firms, owners have direct control over business decisions, including how to manage their workforce (Walker and Brown 2004). Owners' decisions in this regard may be influenced by their past life experiences and their experiences with others. In this paper, we consider this by asking, how do the past employment experiences of small IT owners affect firms' offering and facilitation of FWPs? A life course perspective is taken to examine this potential influence. In particular, we draw on the timing of lives principle, which presumes that individuals vary in their timing, sequencing, and duration of life course transitions which in turn, affect subsequent life course experiences (Elder et al. 2003).

Some may doubt the influence of personal experiences on a small firm because of the effect of structural factors, such as class interests that come with being an owner of production, on the organization of work (see e.g., Marx 1961 [1887]; Friedman 1977). The life course of powerful individuals, however, has yet to be examined in the literature as a potential factor contributing to FWPs in small firms and should not be dismissed. Small firms typically have few formalized rules and procedures governing workers' behaviours (Edwards 1979; Kalleberg et al. 1996). Here, the impact of owners' personal opinions and experiences may be greater than in larger firms. Also, the timing of lives life course principle appreciates the influence of cultural expectations on the timing of individuals' lives and their current experiences. Our consideration of owners' past experiences includes how structured social relations were, and are experienced through the workplace.

Structured social relations include class, age, gender, and ethnic and racial relations (McMullin 2010 [2004]). Gender and age relations, 
for example, are embedded in workplace cultures through the idealized behaviour of working long hours (Blair-Loy and Wharton 2002, 2004; Duerden Comeau and Kemp 2011; Hochschild 1997; Ranson and Dryburgh 2011). This behaviour is often perceived to be indicative of a worker's commitment and competence. As researchers have shown, women and people in their child-bearing and child-raising years are particularly disadvantaged in these cultural environments. Owners' previous experiences with these types of workplace cultures - and whether they perceived them to be positive or negative - may shape their decisions and policies in their current firms. If this is the case, we would expect some variability in FWP availability and use across small firms.

\section{Data AND Methods}

\section{Sample}

This paper draws on a Canadian study of information technology (IT) workers in small firms. The sample was drawn from three cities using online local business directories and key informants. Of the 43 firms asked to participate as a case, 18 agreed yielding a 42 percent response rate. Fieldwork took place in 2004 and 2005. For some types of analyses, these data may be considered outdated. However, this is not a particular issue for the present study because FWPs are slow to change and because the analysis herein contributes theoretical insights into how FWPs are used and developed in small firms.

Data for this analysis are taken from multiple data sources collected at 17 small firms employing between 4 and 21 employees. One case was omitted because it was a placement agency and accordingly, respondents did not work at the same firm. Data include 103 self-administered websurveys, 136 in-depth interviews, and 17 case study reports and snapshots, which researchers wrote to summarize the broad themes of a case. ${ }^{2}$ Also used are observational notes taken by researchers about the firm and archival data (i.e., HR policy documents) when available.

The majority of the 17 firms were operative for 10 years or less (59 percent) and specialized in software and web development (76 percent). The remaining firms were operative for more than 10 years (41 percent) and specialized in either consulting (18 percent) or systems analysis and support (six percent). Also, five firms were family-owned (29 percent). To be considered family-owned, there had to be at least two family mem-

2. Not all of the interview respondents participated in the web-survey $(n=43)$ and a few web-survey participants were not interviewed $(n=8)$. 
bers working in the business and at least one of them had to own 50 percent or more of the business (Moshavi and Koch 2005).

Respondents in our firms are typical of IT workers in Canada (see Gunderson et al. 2005). The field is dominated by men and younger workers; indeed, workers who are 40 years of age or older are considered "old" (McMullin and Duerden Comeau 2011). In our sample, the average age of respondents was 37 years. The majority were male (77 percent), white (97 percent), married or in a long-term relationship (65 percent), and a parent (54 percent). Twenty-five percent of respondents were single or never-married and 10 percent were divorced or separated. Despite the inclusion of the dimension of ethnic and racial relations in our conceptual framework, little can be made of ethnicity and race in the data due to the sample's homogeneity.

\section{Data analysis}

This paper aims to enhance the limited knowledge on FWPs in small firms, particularly why small firms offer FWPs to their employees. We ask, how do the past employment experiences of small IT firm owners affect their firms' offering and facilitation of FWPs? We use a multiple case study approach to answer this question. A case study approach presents complexities and contradictions that are difficult to summarize neatly but are reflective of real life and possibly the nature of FWPs in different firms (Fox and Sugiman 1999; Lewis et al. 2006; Marshall 1999). Marshall (1999) advises that a multiple case analysis be "interpretive" whereby theoretical and contextual considerations inform the reasoning.

Before cases were compared, a comprehensive understanding of each small firm and its FWPs was gained. NVivo software was used to help organize the qualitative data. Predetermined codes from the literature included the availability and use of HR policies and related practices including FWPs, reciprocity (a condition attached to the use of FWPs that requires employees to work long hours), firm support (whether supervisors and colleagues support FWPs and are sympathetic to work-life challenges), firm barriers (the expected and actual hours of work, career consequences for using FWPs), and the employment and family transitions of individuals (see e.g., Andreassi and Thompson 2008; Atkinson and Hall 2009; Blair-Loy and Wharton 2002, 2004; Hochschild 1997). Themes that emerged from multiple readings of the qualitative data were also coded and include other forms of reciprocity (employees use FWPs in exchange for giving back time missed from work and/or completing 
their work tasks), and disappointment with, or confusion over, FWPs or other HR benefits.

The coded data were used to write a profile of a firm's FWPs, workplace culture with respect to time, and the life course transitions and experiences of its members. Data on FWPs from the web-surveys were integrated into these firm profiles. These contextual documents facilitated the comparison of multiple cases. Firm names have been replaced with pseudonyms.

\section{Results}

In the sections that follow, we first describe the availability of FWPs in the small firms in our sample, and the extent to which FWPs were utilized by employees. We then identify under which conditions FWPs are available for use. Based on these characteristics, we create a typology of small firms. Next, we discuss how these small firms vary by firm type in terms of the attitudes towards working hours, and other characteristics. Lastly, we explore the employers' past employment experiences, and examine how these appear to have shaped FWP use.

\section{Cross-firm comparisons based on FWPs}

Only one small firm had HR policies that included FWPs; whereas all firms had at least one FWP that was available informally. Past research, however, has shown that available FWPs often go unused because doing so contrasts idealized behaviours discussed earlier in this paper (Andreassi and Thompson 2008; Blair-Loy and Wharton 2002; Hochschild 1997). Accordingly, FWPs that were actually used by employees in the small firms we studied are our focus. Table 1 shows the number of different types of FWPs used across firms; a FWP is counted when at least one employee has used it. Results are obtained from the web-survey and interview data. ${ }^{3}$ Whereas web-survey respondents answered questions about the FWPs used personally (flex-time, compressed work-week, job sharing, and retirement transition schedule), interview respondents discussed the FWPs used by themselves and others at the firm. In the qualitative data, FWPs were counted as used if descriptions of work arrangements involved changes to the timing or place of work, or the number of hours worked. This approach enabled FWPs that are not identified in the web-survey to be included; examples include working from home, a

3. When over four FWPs were identified as being used from the interview data, the label " $4+$ " is used in Table 1 because the web-survey had a maximum of four options of FWPs that could be used. 
half-day on Fridays, and variable work days (leave early one day, work later day), among others. We consider firms in which zero or one FWP(s) were used as relatively inflexible compared to firms in which three or more FWPs were used. Firms with two FWPs used are more difficult to distinguish as either flexible or inflexible without further information about the context of each firm.

Table 1: Flexible Workplace Practices Used and the Associated Conditions

\begin{tabular}{|c|c|c|c|c|}
\hline Case pseudonym & $\begin{array}{l}\text { Case } \\
\text { no. }\end{array}$ & $\begin{array}{l}\text { FWPs used } \\
\text { (total \#) from } \\
\text { web-survey }\end{array}$ & $\begin{array}{l}\text { FWPs used } \\
\text { (total \#) from } \\
\text { qualitative data }\end{array}$ & $\begin{array}{l}\text { Conditions associated with } \\
\text { the use of FWPs }\end{array}$ \\
\hline E\&C Solutions & 101 & 0 & 1 & owe-back-time; face-time \\
\hline FC Software & 104 & 1 & 1 & owe-back-time \\
\hline Consyst & 107 & 3 & 1 & owe-back-time; face-time \\
\hline WebBytes & $111 / 9$ & 1 & 1 & owe-back-time \\
\hline ComTech & 117 & 2 & 2 & owe-back-time; face-time \\
\hline Net Host & 102 & 0 & 3 & $\begin{array}{l}\text { get-work-done } \\
\text { flexibility-for-flexibility }\end{array}$ \\
\hline Custom Software & 103 & 0 & 2 & get-work-done \\
\hline Biz Software & 105 & 0 & 2 & get-work-done \\
\hline Online Design & 106 & 0 & 2 & flexibility-for-flexibility \\
\hline GP Solutions & 108 & 1 & 2 & get-work-done \\
\hline A\&S Systems & 109 & 1 & 2 & get-work-done \\
\hline SoftBytes & 110 & 3 & $4+$ & $\begin{array}{l}\text { get-work-done } \\
\text { flexibility-for-flexibility }\end{array}$ \\
\hline SysSolutions & 112 & 1 & 2 & flexibility-for-flexibility \\
\hline IT Consulting & 113 & 1 & 2 & $\begin{array}{l}\text { get-work-done } \\
\text { flexibility-for-flexibility }\end{array}$ \\
\hline PSIT & 114 & 2 & 3 & $\begin{array}{l}\text { get-work-done } \\
\text { flexibility-for-flexibility }\end{array}$ \\
\hline $\begin{array}{l}\text { Interface } \\
\text { Consulting }\end{array}$ & 115 & 1 & $4+$ & $\begin{array}{l}\text { get-work-done } \\
\text { flexibility-for-flexibility }\end{array}$ \\
\hline Advanced Chips & 116 & 4 & $4+$ & $\begin{array}{l}\text { get-work-done } \\
\text { flexibility-for-flexibility }\end{array}$ \\
\hline
\end{tabular}

Source: web-survey and interview data.

The qualitative data revealed three conditions associated with the use of these FWPs. First, in exchange for the use of FWPs, workers were sometimes required to owe the firm back time (the actual or presumed time missed from work and/or the office). Second, workers were expected to reciprocate and be flexible to the firm by working overtime hours when needed. Third, some firms simply required their workers to get their work done in order for the firm to meet its deadlines. Some of these strategies provided workers with more flexibility than others. Firms with cultures in which workers who missed time at work were seen to "owe" the firm time, constrained the use of FWPs by emphasizing the importance of the total number of hours worked and presence at work. These firms appear to use direct control strategies for managing employees. In 
contrast, the other two conditions appear to reflect more indirect control strategies such as responsible autonomy. Responsible autonomy gives workers some leeway in how they perform their day-to-day activities regarding when and where work will be completed (see Friedman 1977, 2000). It is typically employed with highly skilled workers, like IT workers, and can facilitate the use of FWPs.

Based on these measures, overall assessments reveal two ideal types of firms based on their flexibility. First are those firms that are quite inflexible for employees: few to none FWPs were used, and when used, FWPs had time-related conditions attached to them. We refer to the five firms categorized here as "rigid firms." These firms include E\&C Solutions, FC Software, Consyst, WebBytes, and ComTech. Second are the relatively flexible firms that we refer to as "flexible firms." These firms had a diverse range of FWPs used by employees and results-related conditions attached. The twelve firms listed in this classification include: Net Host, Custom Software, Biz Software, Online Design, GP Solutions, A\&S Systems, SoftBytes, SysSolutions, IT Consulting, PSIT, Interface Consulting, and Advanced Chips. Notably, firm size is not a determinant of whether a firm is "rigid" or "flexible."

\section{Working hours and approaches to time across small firms}

Initial analyses revealed that firms vary in terms of the flexibility granted to workers, and their approaches to working time. We examined the average number of hours worked weekly by employees at each firm, as well as the frequency with which workers were asked to work over-time (often, occasionally, or rarely). Table 2 compares rigid firms with flexible firms. As this table shows, rigid firms, on average, tend to require more working hours per week (45.9), than do their flexible counterparts (41.8). Furthermore, flexible firms are more likely to require overtime "rarely." Somewhat surprising, however, are the striking differences among flexible firms with regard to the occurrence of overtime hours, the total amount of working hours, and even the reciprocal exchanges that take place for the use of FWPs. In fact, two sub-categories emerged.

We classify flexible firms in which overtime hours were often worked as having workplace cultures that are "contradictory" to the use of FWPs. Three firms are considered flexible/contradictory: Online Design, Net Host, and SysSolutions. In these firms, work was based on the expectation that workers could use FWPs in exchange for being flexible through overtime hours. But because long hours were continuously worked, employees were more flexible to the firm than the firm was to them. In the remaining nine firms, overtime hours were occasionally-to- 
rarely worked; hence these workplaces were "favourable" to the use of FWPs. Also, employees worked on the basis of getting their work done, and in five of these firms, employees had to be flexible back to the firm occasionally. Flexible/favourable firms include Custom Software, Biz Software, GP Solutions, A\&S Systems, SoftBytes, IT Consulting, PSIT, Interface Consulting, and Advanced Chips. The workplace cultures of flexible/favourable firms had a more balanced view of individuals' working and non-working lives compared to flexible/contradictory firms.

Table 2: Time-Related Workplace Culture Dimensions of Rigid and Flexible Firms

\begin{tabular}{|c|c|c|c|c|}
\hline $\begin{array}{l}\text { Case } \\
\text { pseudonym by } \\
\text { firm-type }\end{array}$ & $\begin{array}{l}\text { Case } \\
\text { no. }\end{array}$ & $\begin{array}{l}\text { Average } \\
\text { number of } \\
\text { hours per } \\
\text { week (mean) }\end{array}$ & $\begin{array}{l}\text { Occurrence of } \\
\text { overtime hours } \\
\text { worked (often, } \\
\text { occasionally, rarely) }\end{array}$ & $\begin{array}{l}\text { Forms of reciprocity } \\
\text { present (conditions } \\
\text { associated with the use of } \\
\text { FWPs) }\end{array}$ \\
\hline Rigid firms & & 45.9 & & \\
\hline E\&C Solutions & 101 & 50.4 & Often & $\begin{array}{l}\text { owe-back-time } \\
\text { face-time }\end{array}$ \\
\hline FC Software & 104 & 49.3 & Often & owe-back-time \\
\hline Consyst & 107 & 44.1 & Occasional & $\begin{array}{l}\text { owe-back-time } \\
\text { face-time }\end{array}$ \\
\hline WebBytes & $111 / 9$ & 42.9 & Rare & owe-back-time \\
\hline ComTech & 117 & 43 & Occasional & $\begin{array}{l}\text { owe-back-time } \\
\text { face-time }\end{array}$ \\
\hline Flexible firms & & 41.8 & & \\
\hline Net Host & 102 & 46.8 & Often & $\begin{array}{l}\text { get-work-done } \\
\text { flexibility-for-flexibility }\end{array}$ \\
\hline $\begin{array}{l}\text { Custom } \\
\text { Software }\end{array}$ & 103 & 35.0 & Rare & get-work-done \\
\hline Biz Software & 105 & 38.5 & Rare & get-work-done \\
\hline Online Design & 106 & 42.7 & Often & flexibility-for-flexibility \\
\hline GP Solutions & 108 & 41.5 & Rare & get-work-done \\
\hline A\&S Systems & 109 & 37.8 & Rare & get-work-done \\
\hline SoftBytes & 110 & 43.4 & Occasional & $\begin{array}{l}\text { get-work-done } \\
\text { flexibility-for-flexibility }\end{array}$ \\
\hline SysSolutions & 112 & 47.9 & Often & flexibility-for-flexibility \\
\hline IT Consulting & 113 & 45.1 & Occasional & $\begin{array}{l}\text { get-work-done } \\
\text { flexibility-for-flexibility }\end{array}$ \\
\hline PSIT & 114 & 37.3 & Occasional & $\begin{array}{l}\text { get-work-done } \\
\text { flexibility-for-flexibility }\end{array}$ \\
\hline $\begin{array}{l}\text { Interface } \\
\text { Consulting }\end{array}$ & 115 & 41.4 & Occasional & $\begin{array}{l}\text { get-work-done } \\
\text { flexibility-for-flexibility }\end{array}$ \\
\hline Advanced Chips & 116 & 44.2 & Rare & get-work-done \\
\hline
\end{tabular}

Source: Average hours per week are from the web-survey data. Overtime hours and reciprocity are from the interview data.

\section{Comparing firm types}

In order to gain a clearer picture of the different firms, we compare the characteristics of the firms, owners, and employees across types. Little variation occurs based on firm characteristics, such as business specialization or family-ownership. Some variation did emerge with regard to the characteristics of the owners and employees as shown in Tables 3 and 4. 
On average, flexible/favourable firms had more owners and employees who were women and who were relatively older compared with flexible/contradictory and rigid firms, controlling for family-owned firms. Flexible/favourable firm owners also had higher levels of educational attainment and recent experience in the IT industry. The ages of owners and employees in the other firm-types are also noteworthy. The owners and employees were both younger in flexible/contradictory firms. In rigid firms, owners tended to be older and employees were younger. These different characteristics are indicative of the structural processes that influence access to use FWPs and are teased out below in relation to the sources of small firms' FWPs.

Table 3: Characteristics of Owners across Firm-Types

\begin{tabular}{|c|c|c|c|c|c|c|}
\hline \multirow[t]{2}{*}{ Characteristics of owners } & \multicolumn{2}{|l|}{ Rigid firms } & \multicolumn{2}{|c|}{$\begin{array}{l}\text { Flexible and } \\
\text { contradictory firms }\end{array}$} & \multicolumn{2}{|c|}{$\begin{array}{l}\text { Flexible and } \\
\text { favourable firms }\end{array}$} \\
\hline & $\mathrm{n}$ & $\%$ & $\mathrm{n}$ & $\%$ & $\mathrm{n}$ & $\%$ \\
\hline \multicolumn{7}{|l|}{ Ethnicity/Race } \\
\hline Visible minorities & - & - & - & - & - & - \\
\hline Immigrants & - & - & - & - & - & - \\
\hline \multicolumn{7}{|l|}{ Age } \\
\hline $20 \mathrm{~s}$ & - & - & 3 & 50 & - & - \\
\hline $30 \mathrm{~s}$ & 2 & 22.2 & 1 & 16.7 & 7 & 33.3 \\
\hline $40 \mathrm{~s}$ & 2 & 22.2 & 1 & 16.7 & 11 & 52.4 \\
\hline $50 \mathrm{~s}$ & 5 & 55.6 & - & - & 2 & 10 \\
\hline $60 \mathrm{~s}$ & - & - & 1 & 16.7 & 1 & 4.8 \\
\hline Median (in years) & $\begin{array}{l}\text { late } 40 \mathrm{~s}- \\
\text { early } 50 \mathrm{~s}^{1}\end{array}$ & - & 33 & - & 43 & - \\
\hline Range (in years) & $33-58$ & - & $27-62$ & - & $30-60$ & - \\
\hline \multicolumn{7}{|l|}{ Gender } \\
\hline Women & 2 & 22.2 & 1 & 16.7 & 5 & 23.8 \\
\hline $\begin{array}{l}\text { Women in firms not } \\
\text { family-owned }\end{array}$ & - & - & - & - & 3 & 17.6 \\
\hline \multicolumn{7}{|l|}{ Educational attainment } \\
\hline High School & 2 & 22.2 & 5 & 83.3 & 2 & 10 \\
\hline College Diploma & 3 & 33.3 & 1 & 16.7 & 2 & 10 \\
\hline Bachelor's Degree & 4 & 44.4 & - & - & 8 & 38.1 \\
\hline Master's Degree & - & - & - & - & 8 & 38.1 \\
\hline Doctorate Degree & - & - & - & - & 1 & 4.8 \\
\hline Total \# of firm owners & 9 & - & 6 & - & 21 & - \\
\hline
\end{tabular}

Source: interview data.

Note: ${ }^{1} \mathrm{~A}$ range is given because the exact age of some owners was not provided. 
Table 4: Characteristics of Employees across Firm-Types

\begin{tabular}{|c|c|c|c|c|c|c|}
\hline \multirow[t]{2}{*}{ Characteristics of employees } & \multicolumn{2}{|c|}{ Rigid firms } & \multicolumn{2}{|c|}{$\begin{array}{l}\text { Flexible and } \\
\text { contradictory firms }\end{array}$} & \multicolumn{2}{|c|}{$\begin{array}{l}\text { Flexible and } \\
\text { favourable firms }^{1}\end{array}$} \\
\hline & $\mathrm{n}$ & $\%$ & $\mathrm{n}$ & $\%$ & $\mathrm{n}$ & $\%$ \\
\hline \multicolumn{7}{|l|}{ Ethnicity/Race ${ }^{2}$} \\
\hline Visible minorities & 2 & 3 & - & - & 6 & 8.7 \\
\hline Immigrants & - & - & - & - & 6 & 8.7 \\
\hline \multicolumn{7}{|l|}{$\operatorname{Age}^{3}$} \\
\hline$<20$ & - & - & 1 & 5.3 & - & - \\
\hline $20 \mathrm{~s}$ & 17 & 42.5 & 11 & 57.9 & 5 & 12.8 \\
\hline $30 \mathrm{~s}$ & 13 & 32.5 & 5 & 26.3 & 14 & 35.9 \\
\hline $40 \mathrm{~s}$ & 9 & 22.5 & 2 & 10.5 & 14 & 35.9 \\
\hline $50 \mathrm{~s}$ & 1 & 2.5 & - & - & 5 & 12.8 \\
\hline $60 \mathrm{~s}$ & - & - & - & - & 1 & 2.6 \\
\hline Range (in years) & $23-49$ & - & $19-43$ & - & $28-62$ & - \\
\hline Median (in years) & 30 & - & 28 & - & 40 & - \\
\hline \multicolumn{7}{|l|}{ Gender $^{2}$} \\
\hline Women & 15 & 22.7 & 2 & 8.3 & 17 & 24.6 \\
\hline $\begin{array}{l}\text { Women in firms not } \\
\text { family-owned }\end{array}$ & 7 & 12.1 & 2 & 12.5 & 16 & 23.5 \\
\hline \multicolumn{7}{|l|}{ Educational attainment ${ }^{3}$} \\
\hline High School & 2 & 5.0 & $3^{4}$ & 15.8 & 1 & 2.6 \\
\hline College Diploma & 19 & 47.5 & 12 & 63.2 & 13 & 33.3 \\
\hline Bachelor's Degree & 16 & 40 & 4 & 21.1 & 22 & 56.4 \\
\hline Master's Degree & 3 & 7.5 & - & - & 3 & 7.5 \\
\hline $\begin{array}{l}\text { Total \# of employees } \\
\text { interviewed }\end{array}$ & 40 & - & 19 & - & 39 & - \\
\hline $\begin{array}{l}\text { Total \# of individuals } \\
\text { employed at firms }{ }^{5}\end{array}$ & 66 & - & 24 & - & 69 & - \\
\hline $\begin{array}{l}\text { Source: Case studies, snapsho } \\
\text { Notes: }{ }^{1} \text { Two respondents were } \\
\text { are based on the case studies a } \\
\text { based on the interview data. } \\
{ }^{5} \text { This number is derived from } \\
\text { subtracting the number of own }\end{array}$ & $\begin{array}{l}\text { S, and in } \\
\text { exclude } \\
\text { hd snaps } \\
\text { wo of tl } \\
\text { he addit }\end{array}$ & $\begin{array}{l}\text { view d } \\
\text { ecause } \\
\text { ts. Not } \\
\text { e resp } \\
\text { of all }\end{array}$ & $\begin{array}{l}\text { ey were } \\
\text { individ } \\
\text { ents wer } \\
n \text { sizes i }\end{array}$ & $\begin{array}{l}\text { ner empl } \\
\text { have be } \\
\text { college } \\
\text { cated fros }\end{array}$ & $\begin{array}{l}\text { es of a } \\
\text { ntervieu } \\
\text { he time } \\
\text { ne snaps }\end{array}$ & $\begin{array}{l}\text { m. }{ }^{2} \text { Data } \\
\text { d. }{ }^{3} \text { Data are } \\
\text { interviews. } \\
\text { ts and then }\end{array}$ \\
\hline
\end{tabular}

\section{OWNERS' PAST EMPLOYMENT EXPERIENCES AND FWPS AT THEIR SMALL FIRMS}

Patterns emerged in the past employment experiences of rigid and flexible firm owners. In this section, we show how the interaction of the agency of powerful individuals and structural forces helps explain the variation among the three firm-types found. We argue that past employment has lasting effects for owners in the development and facilitation of their small firms' FWPs.

\section{Rigid firm owners}

Most of the nine owners of the five rigid firms did not work in IT prior to their current ownership position (78 percent). These rigid firm owners 
described their previous employment experiences in a scant amount of detail, but made references to their current experiences that are telling of what they expected from their employees.

Like other rigid firm owners, the CEO of FC Software merely named past places of employment without elaborating on his experience. He was a tradesperson and worked at large companies until he started this firm with his wife. Some insight can be gained into how they managed employees through his description of the firm's HR policies. He commented, "We have written policies...about dress code,...office politics, talking to the customers, [and]...doing [work], especially in the development side...[about] coding concepts." (1104016, male, early 50s, CEO). The formalization described is typical of large firms but unusual for small firms. FC Software was one of the three Rigid firms that had HR policies; in total, eight of seventeen firms in the sample had HR policies. When asked if there were reporting hierarchies at FC Software, the CEO said "nope." But when probed if employees felt that they could come to him with any sort of issue, he replied: "I think there are some people [who] are still shy. They look at the position that [my wife] or I have and feel like we're still of authority which is fine. You don't want to change that too much." His comments suggest that the "authority" used in this small firm extended beyond the unstructured control noted earlier that small firm owners are presumed to have over their workers.

Rigid firm owners seemed to favour formalized power differences in their small firms. In one firm, however, the owners had split views about how to manage their employees, which appears to be tied to their past employment experiences. The Chief Technical Officer (CTO) recently worked for a large IT company, whereas the CEO owned a small consulting business operating outside of the IT industry. The CTO commented on his experiences in relation to their firm, ComTech:

The atmosphere...that we've wanted [at ComTech] has been you know an open one, an exciting one... [with] a funky cool feel as opposed to a button-down corporate feel. I've worked in those environments... We really [do] not want...that same environment. (1117084, male, $33 \mathrm{yrs}, \mathrm{CTO})$

The CTO worked in large IT companies throughout his employment pathway but did not elaborate further on these experiences. The CEO had experience working at a large IT company, but it was in the distant past when he was a young graduate. The CEO did not share the CTO's concern to avoid a "button-down corporate feel." Rather, he valued structure which became clear when he spoke of ComTech's HR policies. 
I've been talking to a lot of my friends who work at some big companies... They basically have an all-encompassing vacation policy. You get ' $x$ ' number of weeks [off] and that's it... Whether you want to be sick, you have dentist appointments, whether you want to take [a] vacation, [it] doesn't matter, that's your time off. While our CTO disagrees with that policy, I think [it] is probably the least tenuous way.... and the most equitable. (1117175, male, 36 yrs, CEO)

HR policies were already established at ComTech, which were implemented by the CEO; these policies were originally developed for a large company that did not operate in IT. ComTech's classification as a rigid firm implies that the CTO conceded to the CEO's preference for structure.

In their current positions, rigid firm owners spent a lot of time working. All but one worked heroic hours, over 50 or sometimes 60 hours per week. ${ }^{4}$ The CTO of ComTech commented on the consequence of long hours. He said, "I don't see [my kids] as much as I would like to, in part because I have a lot of work to do... My responsibilities extend not only to my children but also to the employees here." (1117084, male, 33 yrs, CTO). He was able to prioritize his work life because his wife was the primary caregiver of their young children. His comment reflects the circumstances of the other rigid firm owners who treated work as their sole priority in life regardless of whether they had young children. Their consideration of personal life as secondary to work may be indicative of the inflexibility of their firms and their tendency to reproduce traditional gendered and age expectations. Whether or not intentional, rigid firm owners expected their employees to prioritize their working lives as well.

\section{Flexible firm owners}

The sample profiles of the three flexible/contradictory and the nine flexible/favourable firms differed in relation to their age and gender compositions, but these two groups of owners had similar employment experiences and hence are discussed together. Differences in their current employment experiences will be noted.

Most of the twenty-one flexible/favourable firm owners (76 percent) and six flexible/ contradictory firm owners (83 percent) had positions in the IT industry immediately prior to their current ownership position. Considering the tendency of knowledge-intensive firms to employ responsible autonomy, the recent experience in IT may have led these owners to use this management control strategy in their current com-

4. A co-owner of FC Software was the only exception; she was the CEO's wife and mainly performed the business's administrative duties. 
panies. With a few exceptions, these owners did not elaborate on these most recent experiences in IT. Those who did spoke of the autonomy they experienced. Most flexible firm owners described negative experiences from previously working in large companies that were not their prior place of employment. For example, an owner of SysSolutions commented on his past experience:

In a big company you have to have... structure because there [are] just so many people. But even in a big company it's wrong for people to think that because they've got a title of such and such that they're more important than somebody else because they aren't. (1112016, male, 62 yrs, CEO)

His experiences in this large firm shaped his approach to management in his small firm:

I think a small company is making a huge mistake if they try to run [it]... like a big company...Y You really need to make the people [feel] comfortable... Everybody is working towards a common goal and one person isn't any more important than the other person.

Typical of small firms, all study firms lacked HR personnel. Employees were to approach an owner and request to use FWPs. Comfort with small firm owners, then, was imperative because of this informality. Flexible firm owners avoided formalized power relations in their current firms resulting in "comfortable" employment relations. Rigid firm owners did not describe this need to put employees at ease.

The aversion "to run a small company like a big company," was based on previous experience. An owner of Biz Software claimed that while employed at a large company not in the IT industry, he was told: "if you want to succeed here, be prepared to forfeit time. That is the indication of your commitment." (1105016, male, 40 years, CEO). His current business partner also worked at this company. Their past employment experiences seemed to have lasting effects on how they developed Biz Software:

Management does not pressure people to make their timelines if something is happening behind schedule... I don't believe that you can have... a good retention rate of your employees and employee satisfaction and have that conveyed into customer satisfaction in [a] sustainable way with the typical burnout cycle that we place on IT workers. So I want these people to give me a good 8 hours every[day]... In terms of people having to work 60 [or] 70 hours a week for months at a time because they're an IT worker, I don't buy into that. (1105016, male, 40 yrs, CEO) 
Working long hours is not unusual in the IT industry and often accompanies the intense workloads that result for workers from firms' attempts to be competitive. This Biz Software owner attempted to mitigate such pressures, and be supportive of employees' needs which included using FWPs and having time for non-working activities.

One difference between the owners of the two flexible firm types that emerged is with regard to their current employment experiences. The majority of the twenty-one flexible/favourable owners worked between 40 and 50 hours per week ( $n=17)$; only four worked over 50 hours per week. These owners committed more time to their personal lives compared to flexible/contradictory owners. One owner from each of the three flexible/contradictory firms worked at least 50 hours per week; the others worked about 40 hours per week. Regardless of their parental status, the current work-life balance of flexible/contradictory firm owners was heavily weighted on work. Recall that employees of these firms frequently worked overtime (see Table 2). Employees were relatively young and most did not have caregiving responsibilities. Owners of these firms encouraged long hours, intentionally or unintentionally, through their own working behaviours. Age stereotypes of younger workers and gendered expectations that workers are free of dependents and can devote a lot of time to work were reproduced at flexible/contradictory firms but blurred at flexible/favourable firms in which owners and employees were relatively older.

\section{DisCUSSION AND CONCLUSION}

This paper explored the availability and use of FWPs in small firms. Through a multiple case study approach, we find that small firms are quite variable in the extent to which they create a climate where workers can take advantage of FWPs. Further, we find that owners' past employment experiences, and their personal approaches to work-life balance, shape their firms' flexibility.

Past research on small and knowledge-intensive firms leads us to expect that workers will have some autonomy over their work activities as a result of unstructured work environments (Edwards 1979; James 2011; Kalleberg et al. 1996; MacEachen et al. 2008). Having leeway on the job can facilitate the use of FWPs (Hill et al. 2008). Flexible firms, particularly flexible/favourable firms, support this image, but rigid firms do not. Possible explanations for this difference are the lasting effects of structured social relations on small firm owners and paternalistic relations between owners and employees. 
Small firm owners' previous experiences appear to shape their approach to FWPs in their current firms. Many flexible firm owners consciously sought to create a flexible working environment, in response to their experiences in previous work environments that were more or less flexible. Some of them were not successful in this respect, because other aspects of their organization - for instance an emphasis on working overtime - undermined workers' flexibility. In contrast, rigid firm owners (most of whom came from fields other than IT - a field known for its flexibility) tried to adopt the formal, somewhat rigid policies of larger firms, and apply them to their smaller enterprises. This connection between past and present reflects the "timing of lives" life course principle discussed earlier in this paper. This concept illuminates the relationship between structure and agency over time. For example, the time pressures that typically marked the past employment experiences of flexible firm owners reflect how class relations were negotiated in ways that presumed workers would inherently disrupt the labour process without close supervision. Such pressures are also gendered and reflect assumptions that younger (male) workers can prioritize their working lives over their personal lives.

The lasting effect of structured social relations on the agency of rigid firm owners is reflected in their conformation to hegemonic structural expectations. These owners did not question the organization of work at their previous places of employment. Rather, some modelled their HR policies and managerial practices after those of large organizations reflecting the mimetic isomorphism of institutional theory (see Davis and Kalleberg 2006). For instance, work was based on time and presence at the office. If employees were absent from the office as a result of using FWPs, they owed hours of work to the firm, regardless of whether full-time hours were performed. Hegemonic class, age, and gendered expectations that are often embedded in contemporary workplaces were either considered acceptable or not questioned by rigid firm owners who, in turn, conformed to them. Accordingly, responsible autonomy was not employed.

The intersection of class, age, and gender relations also shaped the structure and culture found in the rigid IT firms. The age of small firm owners influences how they manage, with older owners more likely to be paternalistic compared to younger owners (Ranson and Dryburgh 2011). The findings of this paper suggest that the ages of both owners and workers matter. The age combination of older owners (median= late 40s/early $50 \mathrm{~s}$ ) and younger workers (median= 30 years) is unique to rigid firms in our sample. Notably, owners and workers at these firms were predominantly men (78 percent and 77 percent, respectively). Together, this age 
difference and male dominance may have led owners to mistrust their employees to work in the firms' interests. For instance, a rigid firm owner commented that his firm had HR policies governing workers' behaviours with respect to how they dressed, talked to customers, and treated their colleagues at work. Possibly, these rules are implemented to make younger workers responsible workers. Unlike older workers who have commitments in their personal lives and are considered reliable, younger workers are presumed to be free of dependents (Duerden Comeau and Kemp 2011) and thus, unreliable. Whether control was a response to the younger workforce or whether older workers stayed away from rigid firms to avoid management's direct control strategies, is difficult to discern. What is clear is the importance of considering age dynamics when studying small, knowledge-intensive firms.

In closing, this analysis has some limitations that future research can help to overcome. Notably, the small firms in this study were situated in the IT industry. It is possible that the FWPs and workplace cultures of small firms in other industries are quite different. The IT industry is considered an exemplar of the new economy because risk, opportunity, and uncertainty are at the fore (Duerden Comeau 2003). This context may have influenced the high workloads and continuous or periodic long hours of work among some of the study firms. Also, the management control strategy of responsible autonomy may not be as commonly used by firms in other industries. Comparing small firms in other industries would allow researchers to address the impact of industry on workers' access to FWPs, and on the ways employers' experiences shape managerial strategies.

Future research should also explore workplace cultures and policies as they evolve over time. This present study captured only a moment in time at the firms examined. These firms were successfully surviving in their markets, for the time being, but FWPs and workplace cultures can change with changes to the broader market or environment in which firms operate. According to institutional theory, firms may mimic each other with regard to their HR benefits in uncertain times. We recommend exploring the supply and demand of labour over time in relation to firm's benefits, including FWPs. Whether firms are examined over time through longitudinal or in-depth retrospective studies, connecting firms to the economic context would be helpful to understand the circumstances of the actions of small firm owners.

In spite of these limitations, this paper provides two key insights into why some small firms do and others do not offer and facilitate the use of FWPs. One is that in small firms, the availability and use of FWPs needs to be examined in connection to the owners' beliefs about how 
work should be completed. This paper showed that negotiations between employees and employers about FWPs in the context of small firms are not between equitable or neutral individuals; owners are a powerful, not indifferent, party who can make the work environment comfortable or uncomfortable for workers to make any requests. The second contribution includes the possible ways that institutional theory can be used to explain why some firms do and others do not offer or support the use of FWPs. Despite being less visible to the public, small firms may conform to institutional pressures, intentionally or unintentionally. Some small firm owners rely on previous employment experiences in large companies and reproduce the workplace practices and structures in their own firms. Other small firm owners find such formalized workplace environments unacceptable and resist this isomorphism. These insights enhance our previous limited understanding of FWPs in small firms, but there are still many questions surrounding the dynamics of FWP availability and use in small firm environments.

\section{REFERENCES}

Andreassi, Jeanine K. and Cynthia. A. Thompson. 2008. Work-family culture: Current research and future directions. In Handbook of Work-Family Integration, edited by K. Korabik, D. S. Lero, and D. L. Whitehead, 331351. London: Academic Press.

Atkinson, Carol and Laura Hall. 2009. The role of gender in varying forms of flexible working. Gender, Work and Organization 16(6): 650-666.

Blair-Loy, Mary and Amy S. Wharton. 2002. Employees' use of work-family policies and the workplace social context. Social Forces 80(3): 813-45.

Blair-Loy, Mary and Amy S. Wharton. 2004. Organizational commitment and constraints on work family policy use: Corporate policies in a global company. Sociological Perspectives 47(3): 243-267.

Christensen, K., \& Schneider, B. (Eds.). 2010. Workplace Flexibility: Realigning $20^{\text {th }}$ Century Jobs for a $21^{\text {st }}$ Century Workforce. Ithaca: ILR Press.

CNN. 2014. Best companies to work for: Best benefits: Work-life balance. Money February. Retrieved from http://money.cnn.com/magazines/fortune/best-companies (February 9, 2014).

Davis, Amy E. and Arne L. Kalleberg. 2006. Family-friendly organizations? Work and family programs in the 1990s. Work and Occupations 33(2): 191-223.

Dex, Shirley and Fiona Scheibl. 2001. Flexible and family-friendly working arrangements in UK-based SMEs: Business cases. British Journal of Industrial Relations 39(3): 411-31. 
DiMaggio, Paul J. and Walter W. Powell. 1983. The iron cage revisited: Institutional isomorphism and collective rationality in organizational field. American Sociological Review 48(2): 147-160.

Duerden Comeau, Tammy. 2003. Information Technology (IT) Employment: What is IT? WANE Working Paper no. 1. London, ON: The University of Western Ontario, Workforce Aging in the New Economy (WANE).

Duerden Comeau, Tammy and Candace L. Kemp. 2011. Variants of masculinity within masculinist IT workplace regimes. In Gender, Age and Work: Small Information Technology Firms in the New Economy, edited by J. A. McMullin, 59-80. Vancouver: UBC Press.

Duxbury, Linda and Chris Higgins. 2003. Work-Life Conflict in Canada in the New Millennium: A Status Report. Ottawa: Public Health Agency of Canada.

Eaton, Susan C. 2003. If you can use them: Flexibility policies, organizational commitment, and perceived performance. Industrial Relations 42(2): 145-167.

Edwards, Richard. 1979. Contested Terrain. New York: Basic Books.

Elder, Glen. H., Jr., Monica K. Johnson and Robert Crosnoe. 2003. The emergence and development of life course theory. In Handbook of the Life Course, edited by J. T. Mortimer and M. J. Shanahan, 3-19. New York: Klywer Academic/Plenum Publishers.

Ferrer, Ana and Lynda Gagné. 2006. The Use of Family Friendly Workplace Practices in Canada. IRPP Working Paper Series. No. 2006-02. Retrieved on June 5, 2012 from (http://www.irpp.org/wp/archive/wp200602.pdf).

Fox, Bonnie and Pamela Sugiman. 1999. Flexible work, flexible workers: The restructuring of clerical work in a large telecommunications company. Studies in Political Economy 60: 59-84.

Friedman, Andrew L. 1977. Industry and Labour: Class Struggle at Work and Monopoly Capitalism. London: Macmillan.

Friedman, Andrew L. 2000. Microregulation and post-Fordism: Critique and development of regulation theory. New Political Economy 5(1):59-76. Gunderson, Morley, Lee Jacobs and François Vaillancourt. 2005. The Information Technology (IT) Labour Market in Canada: Results from the National Survey of IT Occupations. Ottawa: Software Human Resource Council (SHRC).

Higgins, Chris, Linda Duxbury and Sean Lyons. 2008. Reducing Work-Life Conflict: What Works? What Doesn't? Health Canada. Retrieved from http:// www.hc-sc.gc.ca/ewh-semt/pubs/occup-travail/balancing-equilibre/ index-eng.php (May 31, 2013). 
Hill, E. Jeffrey, Joseph G. Grzywacz, Sarah Allen, Victoria L. Blanchard, Christina Matz-Costa, Sandee Shulkin and Marcie Pitt-Catsouphes. 2008. Defining and conceptualizing workplace flexibility. Community, Work \& Family 11(2): 149-163.

Hochschild, Arlie. 1997. The Time Bind: When Work Becomes Home and Home Becomes Work. New York: Metropolitan Book.

Industry Canada. 2013. Key Small Business Statistics. Ottawa: Industry Canada. Retrieved from http://www.ic.gc.ca/sbstatistics (February 7, 2014).

James, Al. 2011. Work-life (im)'balance' and its consequences for everyday learning and innovation in the New Economy: evidence from the Irish IT sector. Gender, Place \& Culture 18(5): 655-684.

Kalleberg, Arne. L., David Knoke, Peter V. Marsden and Joe L. Spaeth. 1996. Organizations in America: Analyzing their Structures and Human Resource Practices. Thousand Oaks: Sage.

Korabik, Karen, Donna S. Lero and Denise Whitehead. 2008. Handbook of Work-Family Integration. London: Academic Press.

Lero, Donna. S. and Suzan Lewis. 2008. Assumptions, research gaps and emerging issues: Implications for research, policy and practice. In Handbook of Work-Family Integration, edited by K. Korabik, D. S. Lero, and D. L. Whitehead, 371-397. London: Academic Press.

Lewis, Suzan and Cary L. Cooper. 2005. Work-Life Integration: Case Studies of Organisational Change. Hoboken: John Wiley \& Sons.

Lewis, Suzan., Maria das Dores Guerreiro and Julia Brannen. 2006. Case studies in work-family research. In The Work and Family Handbook: MultiDisciplinary Perspectives, Methods, and Approaches, edited by M. PittCatsouphes, E. E. Kossek, and S. Sweet, 489-502. Mahwah: Lawrence Erlbaum.

Lowe, Graham and Grant Schellenberg. 2001. What's a good job? The importance of employment relations. CPRN Research Report. Ottawa: Canadian Policy Research Networks.

MacDermid, Shelley M., Margaret Williams, Stephen Marks and Gabriela Heilbrun. 1994. Is small beautiful? Work-family tension, work conditions and organizational size. Family Relations 43(2): 159-167.

MacEachen, Ellen, Jessica Polzer and Judy Clarke. 2008. "You are free to set your own hours": Governing worker productivity and health through flexibility and resilience. Social Science \& Medicine 66(5):1019-33.

Marshall, Katherine. 2006. Converging gender roles. Perspectives on Labour and Income, 7(7), 5-17. Catalogue no. 75-001-XIE. Ottawa: Statistics Canada. Retrieved from http://www.statcan.gc.ca/pub/75-001x/10706/9268-eng.htm (July 17, 2011). 
Marshall, Katherine. 2009. The family work week. Perspectives on Labour and Income, 10(4): 5-13. Catalogue no. 75-001-XIE. Ottawa: Statistics Canada. Retrieved from http:/www.statcan.gc.ca/pub/75-001-x/2009104/ article/10837-eng.htm (July 17, 2011).

Marshall, Victor W. 1999. Reasoning with case studies: Issues of an aging workforce. Journal of Aging Studies 13(4): 337-389.

Marx, Karl. 1961 [1887]. Capital: A Critical Analysis of Capitalist Production, Vol. 1 ( $3^{\text {rd }}$ ed.). (S. Moore \& E. Aveling, Trans.). (F. Engels Ed.). Moscow: Foreign Languages Publishing House.

McMullin, Julie Ann. 2010 [2004]. Understanding Social Inequality: Intersections of Class, Age, Gender, Ethnicity, and Race in Canada, $2^{\text {nd }}$ edition. Don Mills: Oxford University Press.

McMullin, Julie Ann and Tammy Duerden Comeau. 2011. Aging and age discrimination in IT firms. In Gender, Age and Work: Small Information Technology Firms in the New Economy, edited by J. A. McMullin, 133158. Vancouver: UBC Press.

Meyer, John and Brian Rowan. 1977. Institutionalized organizations: Formal structures as myth and ceremony. American Journal of Sociology 83(2):340-363.

Moshavi, Dan and Marianne J. Koch. 2005. The adoption of family-friendly practices in family-owned firms: Paragon or paradox? Community, Work and Family 8(3): 237-249.

Ollier-Malaterre, Ariane. 2009. Organizational work-life initiatives: Context matters. Community, Work, and Family 12(2):159-178.

Pitt-Catsouphes, Marcie and Leon Litchfield. 2001. How are small businesses responding to work and family issues? In Working Families: The Transformation of the American Home, edited by R. Hertz and N. L. Marshall, 131-151. Berkeley: University of California Press.

Pohlmann, Corinne and Andreea Dulipovici. 2004. Fostering flexibility: Work and family. Results of the CFIB survey on workplace practices. Canadian Federation of Independent Business (CFIB). Retrieved from http:// www.cfib-fcei.ca/english/research/canada/114-social_policy/263-fostering_flexibility_work and family.html (August 14, 2009).

Ranson, Gillian and Heather Dryburgh. 2011. Firms as "gender regimes": The experiences of women in IT workplaces. In Gender, Age and Work: Small Information Technology Firms in the New Economy, edited by J. A. McMullin, 35-58. Vancouver: UBC Press.

Walker, Elizabeth and Alan Brown. 2004. What success factors are important to small business owners? International Small Business Journal 22(6): 577-591.

Zeytinoglu, Isik U., Gordon B. Cooke and Sara L. Martin. 2009. Flexibility: Whose choice is it anyway? Relations Industrielles/Industrial Relations 64(4): 555-574. 
Catherine Gordon is currently Adjunct Professor at Western University in the Department of Sociology. She recently (2012) completed her Ph.D. in Sociology from Western University. Her thesis was entitled Flexible Workplace Practices in Small IT Firms: A Multiple Case Study. She studies work, education, and aging.

Julie McMullin is a Professor of Sociology and Vice-Provost International at Western University. She studies intersectional social inequality in the domains of paid work and families. She has recently published two edited volumes, Age, Gender and Paid Work (UBC Press) and Ageing and Working in the New Economy: Careers and Changing Structures in Small and Medium Size Information Technology Firms (Edward Elgar). McMullin gratefully acknowledges SSHRC for its contributions to her work.

Tracey L. Adams is a professor and chair of the Department of Sociology at Western University. Her research falls within the general areas of the sociology of work, gender, professions, and social inequality. She is currently researching trends in professional regulation, and profession-state relations. 